\title{
Local Community' Perceptions on Tourist Impacts and Associated Development: A Case Study on Sal and Boa Vista Islands
}

\author{
Castillo Canalejo, Ana María \\ Professor (Ph D), Faculty of Business and Law, University of Cordova \\ Puerta Nueva s/n, 14071, Cordova, Spain \\ Núñez Tabales, Julia M \\ Corresponding Author, Professor (Ph D), Faculty of Business and Law, University of Cordova \\ Puerta Nueva s/n, 14071, Cordova (Spain); Email: es2nutaj@uco.es \\ Sánchez Cañizares, Sandra María \\ Professor (Ph D), Faculty of Business and Law, University of Cordova \\ Puerta Nueva s/n, 14071, Cordova, Spain
}

Doi:10.5901/mjss.2016.v7n1s1p383

\section{Abstract}

\begin{abstract}
The local community or residents and their attitudes/ perceptions are a group of essential interest when analyzing and managing the economic, socio-cultural and environmental impact of tourism development in a certain region. This paper analyzes the attitude of the residents of an emerging destination: the islands of Sal and Boa Vista located at the countryarchipelago of Cape Verde (Africa), with respect to tourism, using a questionnaire specifically designed for the purpose of this work. Concretely this paper focuses on the perception of any consequences which this might have for the community and personally, and at the same time its influence to contribute to higher levels of development. The touristic development of a particular region requires the interaction of a series of organizations, and within this framework there is no doubt that the inhabitants cannot stand idly by others conduct the process of tourism planning, which is why it is of such importance to understand their perceptions and expectations. The primary results show that the residents of Sal and Boa Vista, in general terms, have their doubts as to whether tourism development as it is currently managed on the islands is beneficial to the local community. Though both islands show a high potential for tourism progress, it is essential to keep the local community involved in the initiatives for this development.
\end{abstract}

Keywords: Residents; Perception; Tourism development; Cape Verde.

\section{Introduction}

In recent decades, the tourism industry has significantly increased its contribution to global GDP and currently accounts for $9 \%$ of the total GDP worldwide, although important differences exist between countries. As a result of this growth, increasing attention is being paid in the literature to the impact of tourism development on local communities and environments.

Two major factors play an important role in changes in the quality of life of a local community: tourist-resident relations and the development of the tourism industry (Puczko \& Ratz, 2000). These two factors and their consequences directly contribute to residents' level of satisfaction with tourism and its specific components.

Ecotourism, also known as ecological tourism, is a concept that has emerged as a result of the increasing awareness of the need for tourism development that makes a low impact on the environment. Ecotourism, which is defined in the WTO Global Code of Ethics for Tourism, seeks the social and economic well-being of local communities and respect for their culture.

For tourism development to be successful in a given region, it is essential to involve a broad range of stakeholders (Lanquar, 1985; Vargas, 2007; Ribeiro et al, 2013; Imran et al, 2014), including residents of the nucleus of the destination and coastal and inland areas, as well as government, tourism agents and promoters, and the tourists themselves. In less economically developed countries, multi-stakeholder collaboration is crucial to support entrepreneurship education and 
training and marketing innovation for small and medium-sized enterprises to assist with poverty alleviation and tourism development (Carlisle et al, 2013).

In designing tourism development policies, it is crucial to take into account the perceptions and attitudes of local residents (Allen et al, 1988; Ap., 1992; Diedrich and Garcia-Buades, 2009; Gursoy et al., 2002; Ritchie and Inkari, 2006) regarding the impact of tourism development on their community from an economic, sociocultural, and environmental standpoint.

The aim of this article is to analyze the attitudes of residents of the Cape Verde islands of Sal and Boa Vista toward tourism development and the impact of tourism on the community. Following the introduction, a review of the scientific literature on resident perceptions and attitudes is provided in section two. The study area is described in section three, followed by a discussion of the research methodology in section four. Finally, the main results of the research are presented and conclusions are drawn.

\section{Literature Review}

In the early stages of tourism research, little attention was paid to the perceptions and attitudes of local residents toward tourism. Both the literature and destination management organizations were more concerned with analyzing visitor rather than resident satisfaction. In the 1960s, researchers focused exclusively on the positive effects of tourism in developed regions, and even more so in less developed regions (Swain et al., 1998).

In the 1970s, however, attention began to turn toward local residents. According to Marrero (2006), at the end of the 1970s and in the 1980s, many anthropological tourism studies inspired in Marxist theory focused on the negative impacts of tourism development. Although many studies demonstrated the positive economic effects of tourism, others focused on its negative social, cultural, and environmental consequences (Santana, 1997; Anderek et al., 2005).

Murphy (1985) was the first to consider tourism as a sociocultural event in which both residents and tourists interact. Murphy argued that contrary to the tradition of catering exclusively to the interests of tourists, it is necessary to take into account the negative effects of tourism, the interests of the sector, and the effects tourism may have on society. In recent decades, the number of studies on tourism from the perspective of residents has increased considerably (Harril, 2004; Vargas Sanchez, 2007; Monterrubio, 2008; Mazón, 2009; Sook et al, 2014; Lawton et al, 2015). Many of these studies use statistical techniques to determine the relationship between variables that predict residents' attitudes toward tourism (Lindberg \& Johnson, 1997; Ko \& Steward, 2002; Jurowsky \& Gursoy, 2004; Sharma et al., 2008).

Most studies agree that tourism impacts are perceived by the host community in terms of costs and benefits, which can be divided into three types or categories: economic, environmental, and social (Murphy, 1985; Gunn, 1988; Gee et al., 1989; McIntosh \& Goeldner, 1990; Gursoy \& Jurowski, 2000; Gursoy et al., 2002; Vargas, 2007; Cook et al, 2013). Some authors further divide the 'social' category into a social category and a cultural category, thus making for a total of four categories (Andereck et al., 2005).

According to Diaz and Gutierrez (2010), given that several of the impacts converge in the dimensions or categories, it is possible to observe the most important impacts-dimensions by groups or segments. Depending on how each group of residents is affected by the different dimensions, their attitudes toward tourism will differ. Moreover, each group or segment of residents shares common interests which will affect their attitude toward tourists. Thus, positive and negative social, cultural, and economic impacts are closely linked.

Other studies have shown that residents of economically deprived regions are likely to underestimate the costs of tourism development and overestimate its economic benefits (Liu \& Var, 1986; Sheldon \& Var, 1984; Var et al., 1985). Following in this line, residents who have a negative perception of the local economy would be expected to have a positive perception of tourism (Cater, 1987; Harris et al., 1998).

Residents will be more favorable toward tourism development provided they perceive a positive balance in their relationship with tourists or tourism (Allen et al., 1993). However, due to the diversity within host communities, there may be groups which support tourism as being beneficial to their well-being and others which oppose it as being detrimental to their well-being. For this reason, it is important to understand the variety and combination of factors that determine the extent to which the impacts are over- or underestimated in either a positive or negative manner (Diaz \& Gutierrez, 2010).

The economic benefits that residents perceive from tourism development include more employment opportunities (Belisle \& Hoy, 1980; Tyrrell \& Spaulding, 1984; Var et al., 1985; Davis et al., 1988; Ritchie, 1988; Tosum, 2002), increased income (Murphy, 1983; Tyrrel \& Spaulding, 1984; Davies et al., 1988; Lankford \& Howard, 1994; Jurowski et al., 1997), investment opportunities (Sethna \& Richmond, 1978), and business opportunities (Davis et al., 1988). Although host communities tend to perceive the economic effects of tourism positively, their views on tourism development differ: there are those who support development and others who believe that unchecked, unplanned and 
low quality tourism development involves economic costs that weigh heavily on the population (Diaz \& Gutierrez, 2010).

The social impact of tourism on the host community is often conceived as improving the quality of life of residents engaged in tourism-related activities (Mathieson \& Wall, 1982). Tourism can also result in social and cultural benefits (Besculides et al., 2002), such as more recreational opportunities for residents (Keogh, 1990; Liu et al., 1987; Murphy, 1983; Pizam, 1978; Rothman, 1978; Sheldom \& Var, 1984), improved public services and infrastructure (Sethna \& Richmond, 1978; Pizam, 1978), and as a source of social change (Harrison, 1992). Tourism can also enhance pride and cultural identity, cohesion, the exchange of ideas, and knowledge of the local culture (Esman, 1984) as it creates opportunities for cultural exchange and the revitalization of local traditions, increased quality of life and an improved image of the community (Besculides et al., 2002).

However, tourism development may also have costs or negative sociocultural effects. As a source of change, tourism can have a negative effect on traditional family values (Kousis, 1989), lead to cultural commercialization (Cohen, 1988), and create sociocultural conflicts in the host community due to differences in the economic welfare and purchasing power between the host community and tourists (Tosun, 2002). Moreover, residents may adopt the norms and values of tourists in the long term and become culturally dependent on the tourism generating country (Sharpley, 1994). For this reason, tourism is often criticized for its negative sociocultural impact, especially in smaller, more traditional communities (WTO, 1999).

The environmental dimension of tourism also has a positive and a negative side. On the positive side, tourism can be a motivating factor for protecting natural resources and preserving urban designs (Diaz \& Gutierrez, 2010). In other words, it is possible to manage and plan tourism development based on an environmentally responsible model rather than one based on individual interests which seeks to attract large numbers of tourists and where development is largely haphazard and poorly managed by public authorities (Bujosa \& Rossello, 2007).

In terms of residents' attitudes toward tourism, it is important to examine aspects such as the type and extent of interaction between residents and tourists, the importance of the tourism industry for the community, linkages between visitors and the tourism sector, and the general level of community development (Murphy, 1985). As well as these general factors, other more specific factors should also be taken into account, such as having been born in the community (Um \& Crompton, 1987; Cannan \& Hennessy, 1989), length of time residents have been living in the community (Liu \& Var, 1986), age and educational level (Allen et al., 1988), the concentration of tourism in the community (Pizam, 1978), economic dependence on the tourism industry (Long et al., 1990; Madrigal, 1993), and distance between the place where residents live and the main tourist center (Belisle \& Hoy, 1980; Sheldon \& Var, 1984).

As regards factors which influence the perception of the benefits and costs of tourism, Royo and Ruiz (2009) cite dependency on tourism, the level of local development, the use of public resources by the local community, feelings toward the community, and commitment to the community. These factors or determinants vary the intensity or the perceived sense of the impact, be it positive or negative.

\section{Description of the Study Area}

The research was conducted in Cape Verde, specifically on the islands of Sal and Boa Vista. Cape Verde is an archipelago consisting of 10 volcanic islands in the Atlantic Ocean, some 500 kilometers from the coast of Senegal. The islands are spatially divided into two groups: the Barlovento Islands (windward or northern islands), which include Santo Antão, São Vicente, Santa Luzia, São Nicolau, Sal and Boa Vista, and the Sotavento Islands (leeward or southern islands), which include Maio, Santiago, Fogo, and Brava. The country spans an area of 4,033 square kilometers and was a Portuguese colony until it gained independence in 1975. The climate on the islands is hot and dry, with an average temperature of $20^{\circ}-25^{\circ} \mathrm{C}$ year round, which is a very favorable factor for tourism. 


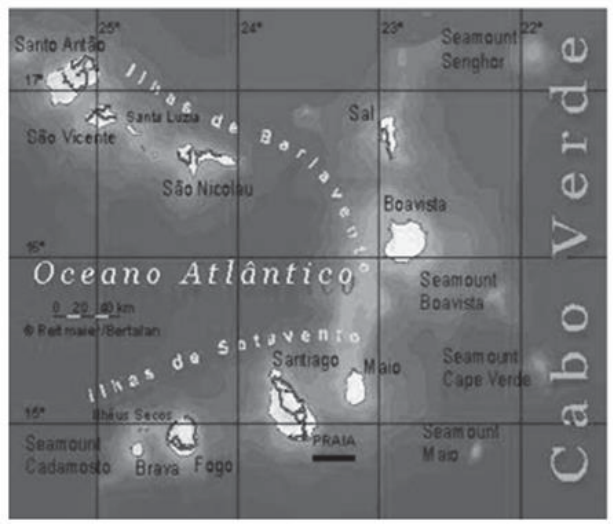

Figure 1: Map of Cape Verde

Source: http://www.islascaboverde.com/mapa-de-cabo-verde.asp

Cape Verde has a population of 524,833 inhabitants, with an annual average growth of $1.23 \%$ (National Cape Verdean Statistics Institute, 2015), although the difficult living conditions in the archipelago have forced thousands of Cape Verdeans to emigrate in order to find work. Cape Verde has a multi-party democracy and is praised as an example among African countries for its political freedom, freedom of the press, and civil liberties. Since 1980, it has stood out among African countries for its economic development, which became evident when it was removed from the list of least developed countries and acquired the status of middle-income country on 1 January 2008.

The economic structure of Cape Verde is conditioned by its insularity and vulnerability to foreign markets. This has led to financial and technical difficulties for the development of energy, water, healthcare, and transport infrastructures, as well as increased production costs since the country depends heavily on imports to survive. Because Cape Verde suffers from frequent droughts, the country is able to produce only $20 \%$ of grain crops for domestic consumption. Nonetheless, the potential for tourism development in Cape Verde is high as it is a safe and attractive location with a good climate year round. The fact that the country maintains good relations with the diaspora, has advanced towards democracy, and occupies a strategic position on a major trade route adds to Cape Verde's potential for development.

The growth of tourism on the islands has led to a boom in the construction sector, although most tourism projects are financed principally by foreign investors. In general terms, the annual revenues generated by tourism have increased. In the period 2000-2014, the contribution from tourism to the GDP grew from a modest $9.1 \%$ to nearly $21 \%$. In the stage previously considered, the number of international arrivals increased by $369.2 \%$, reaching a total of 539,621 tourist arrivals in 2014 (National Institute of Statistics, 2015).

The tourism market in Cape Verde is very diverse, with each island providing different tourism offerings. Because of this, tourism is being managed in two different ways. On the "sun and sand" islands (Sal and Boa Vista) large allinclusive resorts have been built primarily with foreign capital. In contrast, on the islands offering rural and cultural tourism (Santo Antao, Fogo, Santiago, Sao Nicolau, and Sao Vicente) small, community-based tourism businesses have been set up with remittances sent by expatriates.

The islands of Sal and Boa Vista are renowned for their white dunes, remote beaches, and crystal-clear, turquoise water, making them ideal for water sports, such as windsurfing and diving. Although rainfall is scarce, the islands have many natural resources, including sea turtles, bird colonies and coral reefs, making them of high ecological value. All of these factors have attracted large hotel chains, which have invested in all-inclusive resorts, as mentioned above. 


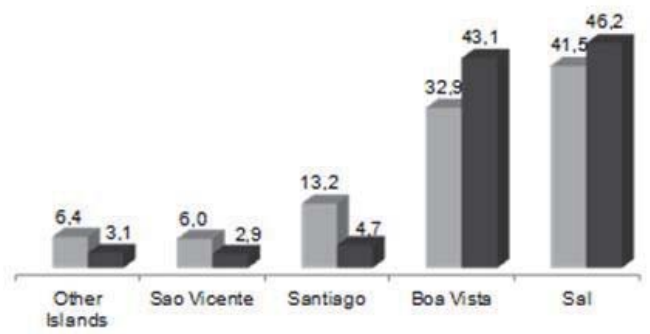

Figure 2: Tourist arrivals and overnight stays (\%) by island, 2014

Source: Cape Verde Institute of Statistics (2014)

According to the most recent statistics published by the National Institute of Statistics, Sal Island received the most visitors, accounting for $41,5 \%$ of total arrivals during the year 2014, followed by Boa Vista with $32.9 \%$, and Santiago with 13.2\%. A similar trend can be observed with regard to number of overnight stays: Sal ranks first with $46.2 \%$, followed by Boa Vista with $43.1 \%$, and Santiago with $4.7 \%$ (Fig. 2).

In 2014, 51.5\% of the total number of beds in the country was concentrated on Sal, followed by Boa Vista with $26 \%$, and Santiago with $9.1 \%$.

The main hotel chains on the islands are RIU, Iberostar and Sol Melia. RIU has four all-inclusive, five-star beachfront hotels (two on Sal and two on Boa Vista), while Iberostar has one all-inclusive, four-star hotel on the island of Boa Vista, and there is a five-star Sol Melia resort on the island of Sal.

\section{Empirical Study}

\subsection{Methodology}

To perform the research, a survey was developed to analyze the attitudes of residents of Sal and Boa Vista toward tourism, with special emphasis on residents' perception of the impact of tourism on the community. The respondents were chosen by simple random sampling. The survey was conducted by interviewers who were trained specifically for the task. A pre-test consisting of fifteen surveys was performed in order to detect possible deviations and errors. The total number of valid surveys was 251. The field work was carried out from February to September 2011. The measurement instrument consisted of a 23-item questionnaire to gather the residents' sociodemographic data, their opinions about the characteristics and development of tourism, and their tourist profile.

The SPSS 22.0 statistical package was used to tabulate and analyze the data. Statistical analysis techniques were used to obtain the corresponding results.

\subsection{Results and Discussion}

As regards the sociodemographic characteristics of the residents of Boa Vista and Sal (Table 1), a relative balance between sexes was observed, with a slight predominance of males. The residents of the islands are mostly young (more than $89.9 \%$ are less than 44 years old, while almost $60 \%$ are less than 30 years old) and live permanently on the islands (more than $70 \%$ have been living on the islands for more than 7 years). The majority of respondents are single (75.6\%) and have a secondary education. A significant number (88.8\%) earn less than 65,000 Cape Verdean escudos per month and $63.5 \%$ of the respondents are employed (63.5\%).

Table 1: Sociodemographic characteristics

\begin{tabular}{|ccc|}
\hline Variable & Category & Percentage \\
\hline \multirow{2}{*}{ Sex } & Male & $57.4 \%$ \\
& Female & $42.6 \%$ \\
\hline \multirow{2}{*}{ Age } & $18-29$ years & $55.9 \%$ \\
& $30-44$ years & $34 \%$ \\
\hline
\end{tabular}




\begin{tabular}{|c|c|c|}
\hline & $\begin{array}{c}45-64 \text { years } \\
65 \text { years or older }\end{array}$ & $\begin{array}{l}7.0 \% \\
3.1 \%\end{array}$ \\
\hline \multirow{5}{*}{ Years living on the island } & Less than 2 years & $8.5 \%$ \\
\hline & $2-6$ years & $19.0 \%$ \\
\hline & $7-10$ years & $24.7 \%$ \\
\hline & $11-20$ years & $14.2 \%$ \\
\hline & More than 20 years & $33.6 \%$ \\
\hline \multirow{4}{*}{ Marital status } & Married or civil union & $17.8 \%$ \\
\hline & Single & $75.6 \%$ \\
\hline & Widowed & $5.6 \%$ \\
\hline & Divorced & $1.0 \%$ \\
\hline \multirow{5}{*}{ Educational level } & No schooling & $5.6 \%$ \\
\hline & Primary & $25.2 \%$ \\
\hline & Secondary & $60 \%$ \\
\hline & University & $5.2 \%$ \\
\hline & Other & $4 \%$ \\
\hline \multirow{6}{*}{ Net monthly income } & Less than 65,000 escudos & $88.8 \%$ \\
\hline & $65,000-100,000$ escudos & $9.6 \%$ \\
\hline & $100,000-165,000$ escudos & $1.3 \%$ \\
\hline & $165,000-200,000$ escudos & $0.0 \%$ \\
\hline & $200,000-265,000$ escudos & $0.3 \%$ \\
\hline & More than 265,000 escudos & $0.0 \%$ \\
\hline \multirow{8}{*}{ Work/Labor Statistics } & Unemployed & $15.2 \%$ \\
\hline & Employed & $63.5 \%$ \\
\hline & Self-employed & $6.1 \%$ \\
\hline & Civil servant & $7.8 \%$ \\
\hline & Retiree/Pensioner & $2.5 \%$ \\
\hline & Student & $3.3 \%$ \\
\hline & Housewife & $1.6 \%$ \\
\hline & Other & $0.0 \%$ \\
\hline
\end{tabular}

The majority of the islands' residents are linked to the tourism sector either because they have been employed in the sector or have or have had a family member that works or worked in the sector (Table 2). The majority of respondents stated that they would like to work or continue working in tourism-related establishments.

Table 2: Occupational link between residents and the tourism sector

\begin{tabular}{|lcc|} 
Variable & Category & Percentage \\
\multirow{2}{*}{ Would like to work in the tourism sector in the future } & Yes & $73.4 \%$ \\
& No & $26.6 \%$ \\
\hline \multirow{2}{*}{ Work is or was related to tourism } & Yes & $70.9 \%$ \\
& No & $29.1 \%$ \\
\hline \multirow{2}{*}{ A family member has worked or works in the tourism sector } & Yes & $73.7 \%$ \\
& No & $26.3 \%$ \\
\hline
\end{tabular}

The survey also measured resident satisfaction with the islands' tourism services using a 5-point Likert scale (1-very dissatisfied, 5-very satisfied). The mean scores for satisfaction are shown in Table 3. As the scores indicate, the residents are dissatisfied with the basic services and utilities on the islands such as electricity, water, and the Internet (less than 2). The residents also showed a low level of satisfaction with the economy, public services, recreational opportunities, and social opportunities. The items that scored highest were transportation, especially the islands' international airports. 
Table 3: Mean score for satisfaction with services on the island (5-point scale)

\begin{tabular}{|c|c|c|}
\hline VARIABLE & INCLUDES & MEAN SCORE \\
\hline Public Services & $\begin{array}{l}\text { Fire protection, social and welfare services, police protection, local government, public } \\
\text { health services }\end{array}$ & 2.04 \\
\hline Educational System & Public schools, university courses, professional development & 2.62 \\
\hline Environment & $\begin{array}{l}\text { Geography or territory, environmental conservation, climate, general appearance of } \\
\text { beaches, cities, and towns }\end{array}$ & 2.35 \\
\hline Recreational Opportunities & Cinemas, gyms, parks and green spaces, exhibition halls, museums & 2.21 \\
\hline Economy & Businesses, cost of living, housing (price and availability), employment opportunities & 2 \\
\hline $\begin{array}{l}\text { Social cohesion and } \\
\text { opportunities }\end{array}$ & Cohesion, a culture of association, citizen participation & 2.18 \\
\hline Transport & $\begin{array}{l}\text { Airports } \\
\text { Ports } \\
\text { Ground transportation }\end{array}$ & $\begin{array}{l}3.17 \\
2.81 \\
3.00\end{array}$ \\
\hline Utilities & $\begin{array}{l}\text { Electricity and water } \\
\text { Internet }\end{array}$ & $\begin{array}{l}1.79 \\
1.86\end{array}$ \\
\hline
\end{tabular}

A cluster analysis was performed with the scores, revealing the existence of three distinct clusters (Tables 4 and 5 ). The first and largest cluster (116 cases), generally gave the services an intermediate score, although the scores were lower for cleanliness, wildlife and hiking. Cluster 2, which is the smallest group with only 44 cases, gave a higher score to all of the items, thus indicating that they were more satisfied with the services provided on the islands. Finally, cluster 3 (81 cases) was comprised of residents who gave most items a low score.

\begin{tabular}{|c|c|c|c|}
\hline & \multicolumn{3}{|c|}{ Cluster } \\
\hline & 1 & 2 & 3 \\
\hline Cost of trip & 2.88 & 3.80 & 1.31 \\
\hline Hospitality & 3.93 & 4.21 & 1.79 \\
\hline Environmental conservator & 2.62 & 3.67 & 1.93 \\
\hline Information/Signage & 3.35 & 3.80 & 1.65 \\
\hline Accommodation & 3.63 & 4.33 & 2.11 \\
\hline Restaurants & 3.20 & 4.54 & 2.08 \\
\hline Communications & 3.09 & 3.80 & 1.71 \\
\hline Safety & 2.36 & 3.53 & 1.65 \\
\hline Cleanliness & 2.02 & 4.12 & 2.14 \\
\hline Telecommunications & 2.73 & 4.12 & 1.70 \\
\hline Food & 3.34 & 4.27 & 2.11 \\
\hline Cultural activities & 2.25 & 3.85 & 2.25 \\
\hline Commercial areas & 2.33 & 3.97 & 2.00 \\
\hline Ecology & 2.60 & 3.66 & 2.33 \\
\hline Sun and sand & 4.49 & 4.81 & 3.76 \\
\hline Wildlife & 2.30 & 3.44 & 2.83 \\
\hline Hiking & 2.29 & 4.05 & 2.57 \\
\hline Others & 2.24 & 3.45 & 2.33 \\
\hline
\end{tabular}

Table 5: Number of cases in each cluster

\begin{tabular}{|lr|r|}
\hline Cluster & 1 & 116,000 \\
& 2 & $44,00 \mathrm{C}$ \\
& 3 & $81,00 \mathrm{C}$ \\
Valid & & 241,000 \\
Missing & & $10,00 \mathrm{C}$ \\
\hline
\end{tabular}

After analyzing the frequencies of the socio-occupational variables and filtering the cases for each cluster, the clusters were characterized. The results of the analysis revealed that cluster 1 was comprised mostly of men (59.1\%) between 18 and 29 years of age (62.3\%), who are residents of Boa Vista (65.5\%) that have lived on the island for 7-10 years (25.9\%) and are employed (59.6\%). Cluster 2, which evaluated the services more positively, comprised mostly women (59.1\%) between 18 and 29 years of age (70\%), who also lived on Boa Vista (52.3\%) but have spent more time on the island (33.3\%). In this group, $72.7 \%$ of the residents are self-employed. Finally, cluster 3 , which had the most negative score, consisted of $65.8 \%$ men between 30 and 44 years of age in $38.4 \%$ of the cases. It is interesting to note that the majority of Sal residents (74.3\%) in this group were more dissatisfied with tourism services than their Boa Vista neighbors. 42.3\% of the residents in this group have been living on the island for more than 20 years. 
As regards agreement with greater tourism development in the area (Fig. 3), the majority of those surveyed (76\%) stated that they strongly agree or agree with tourism development on the islands, while only $10 \%$ said they strongly disagree or disagree.

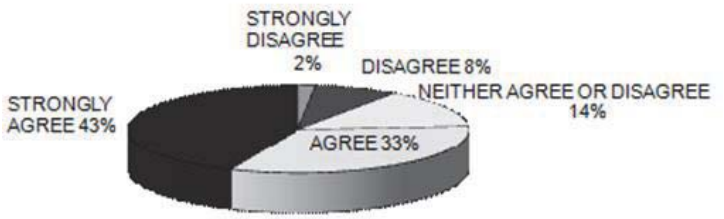

Figure 3: Level of agreement with greater tourism development

The above question is directly correlated to the response to the following item: "To what extent do you think that tourism development can benefit you personally?" (Fig. 4). Of those surveyed, $67 \%$ stated that tourism development could benefit them quite a lot or a lot, while $19 \%$ said that it would benefit them only a little or not at all.

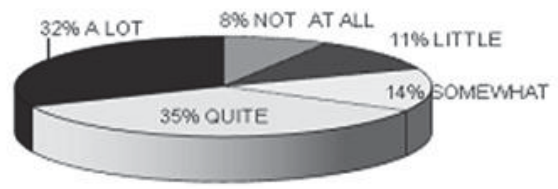

Figure 4: Personal benefit from tourism development (percentage)

As mentioned above, one of the objectives of this research is to analyze residents' perceptions about the positive and negative impacts of tourism. To do so, respondents were asked a series of 5-point Likert scale questions (1-strongly disagree, 5-strongly agree) on the positive and negative effects of tourism (Table 6).

Table 6: Level of agreement about the effects of tourism development on the community (1-5 scale). Positive Effects.

\begin{tabular}{|c|c|c|}
\hline IMPACTS & TYPE OF IMPACT & MEAN SCORE \\
\hline Positive economic impacts & $\begin{array}{l}\text { - Increased investments, development and more airports and infrastructure } \\
\text {-More job opportunities } \\
\text {-Contributes to improving the standard of living } \\
\text {-Increases the island's tax revenues } \\
\text {-Tourism is one of the primary sources of wealth for the economy } \\
\text {-Public investment to attract tourists is good } \\
\text {-Tourism contributes to revitalizing traditional craftsmanship }\end{array}$ & $\begin{array}{l}3.52 \\
3.60 \\
3.42 \\
3.20 \\
3.65 \\
3.43 \\
3.29\end{array}$ \\
\hline Positive social and cultural impacts & $\begin{array}{l}\text {-Better quality of life } \\
\text {-More recreational activities } \\
\text {-Greater understanding of other cultures/countries/ regions } \\
\text {-The island's inhabitants are prouder of being residents } \\
\text {-Improves the quality of service in restaurants, shops, and hotels in the } \\
\text { region } \\
\text {-Improves police and fire protection } \\
\text {-Improves the protection of buildings, monuments, and natural areas }\end{array}$ & $\begin{array}{l}3.34 \\
3.17 \\
3.43 \\
3.41 \\
3.50 \\
3.13 \\
3.26\end{array}$ \\
\hline Positive environmental impacts & $\begin{array}{l}\text {-Better environmental protection } \\
\text {-Improved infrastructure } \\
\text {-Better roads } \\
\text {-More support for the restoration and maintenance of historical buildings }\end{array}$ & $\begin{array}{l}3.26 \\
3.03 \\
3.38 \\
3.40\end{array}$ \\
\hline
\end{tabular}


Table 6 (cont.): Level of agreement about the impact of tourism development on the community (1-5 scale) Negative effects.

\begin{tabular}{|c|c|c|}
\hline IMPACTS & TYPE OF IMPACT & MEAN SCORE \\
\hline Negative economic impacts & $\begin{array}{l}\text {-Higher housing prices } \\
\text {-Higher cost of living } \\
\text {-Higher prices for products and services } \\
\text {-Benefits only a small number of residents } \\
\text {-Benefits of tourism go more to foreign companies and } \\
\text { individuals }\end{array}$ & $\begin{array}{l}3.25 \\
3.31 \\
3.44 \\
3.29 \\
3.38\end{array}$ \\
\hline Negative social and cultural impacts & $\begin{array}{l}\text {-Increase in travel accidents } \\
\text {-Increase in robbery and vandalism } \\
\text {-Increase in alcoholism, prostitution, and sexual } \\
\text { permissiveness } \\
\text {-Increase in illegal gambling } \\
\text {-Increased exploitation of local people } \\
\text {-Change/loss of traditional culture } \\
\text {-Coexistence issues between residents and tourists } \\
\text {-Tourists enjoy privileges that residents do not } \\
\text {-Loss of tranquility in the area }\end{array}$ & $\begin{array}{l}2.89 \\
3.07 \\
3.12 \\
2.97 \\
3.06 \\
3.26 \\
3.28 \\
3.43 \\
3,27\end{array}$ \\
\hline Negative environmental impacts & $\begin{array}{l}\text {-Damage to the landscape } \\
\text {-Destruction of the local ecosystem } \\
\text {-Increase in environmental pollution } \\
\text {-Overcrowding of leisure spaces }\end{array}$ & $\begin{array}{l}3.00 \\
3.23 \\
3.16 \\
3.23\end{array}$ \\
\hline $\begin{array}{l}\text { In general, the benefits of tourism development outweigh } \\
\text { the costs }\end{array}$ & & 2.95 \\
\hline
\end{tabular}

The results showed a generally high level of agreement with the positive effects of tourism (all the mean scores were 3 points or above). More specifically, the respondents stated that tourism was one of the main sources of wealth for the islands, and that it generates employment and improves investments. The level of agreement with the negative effects of tourism was also high (practically all the mean scores were higher than 3 points). The respondents stated that tourism increases the price of products and services and the cost of living in general, while it only benefits a small number of companies or primarily foreign companies. Among those surveyed, a high level of agreement was also observed regarding the question "Tourists enjoy privileges that residents do not have". This is not surprising given that the majority of hotel establishments on the islands of Sal and Boa Vista are all-inclusive resorts with private beaches for the exclusive use of guests staying at the hotels. As a result, visitors to the islands do not usually venture outside the hotel complex, make use of local services, or interact with the community.

A significant correlation was found between the variables related to the perception of positive effects of tourism, support for greater tourist development, and the impact of tourism on personal development. Those who support greater tourism development believe that it will benefit them personally, which in turn includes the positive effects listed in Table 6.

In some cases, a significant correlation was also found between the negative effects of tourism development (Table 7), support for tourism development, and the personal benefits to be gained from tourism. This is the case, for example, of respondents who support development but believe that it will increase housing prices, the cost of living, or the cost of products and services. A correlation was also observed between the majority of variables related to the negative effects of tourism. Specifically, respondents who stated that tourism had a negative effect on one item usually stated that it had a negative effect on the other items as well.

The mean score for the final question as to whether the benefits of tourism outweigh the costs was lower than 3 points. Hence, it is not clear whether the residents of Sal and Boa Vista consider tourism development to be positive as it is currently managed.

\section{Conclusions}

Within the broad range of stakeholders engaged in tourism development, it is important to take into account the perceptions and attitudes of local residents toward the impacts of tourism development on their community from an economic, sociocultural, and environmental perspective. Resident attitudes are a learned response to these impacts and can be of varying intensities and types depending on a multitude of factors that are internal and external to the resident. 
Using the theoretical framework regarding resident attitudes toward tourism development, we have attempted to find a relationship between the different variables that shape residents' attitudes.

Residents' attitudes toward tourism development are a crucial variable that must be taken into account if tourism development is to be planned and managed in a coherent manner. This work has focused on the Cape Verdean islands of Sal and Boa Vista where the sun and sand tourism model is primarily managed by large, all-inclusive hotel chains. In addition to these foreign-owned hotel establishments, small community-based tourism initiatives have been undertaken to gain a share of the market and ensure that the revenues generated by tourism activity also benefit the islands' inhabitants. The results show that although the residents of these islands are largely in favor of tourism development due to the personal benefits they can gain from it, they are also aware of the negative economic, sociocultural, and environmental impacts of poorly managed tourism that does not benefit the community. For this reason, the inhabitants of Sal and Boa Vista have their doubts as to whether the benefits of tourism development outweigh the costs.

In conclusion, the islands of Sal and Boa Vista have a large potential for developing sun and sand tourism. However, to ensure that such a model is sustainable and the islands' residents perceive tourism positively, it is essential to engage the local community in small-scale tourism initiatives that do not impact negatively on the ecosystem. To achieve this aim, public agencies, NGOs and national and foreign universities should strive to educate and raise awareness among the predominantly young population of Sal and Boa Vista to make the islands an example of how properly managed sun and sand tourism can benefit residents and permit sustainable growth.

Future lines of research will have to be directed at exploring changes in the attitudes (given that they are learned responses that feed into one another) of residents on the islands of Sal and Boa Vista, the consistency and validity of tourism impacts and other factors, as well as the overall response of residents over time. Further studies should compare the attitudes and perceptions of residents toward tourism on the different islands of the country, specifically islands with different tourist attractions and management models. The results of this research could be useful for public policymakers and private organizations with a view to managing tourism on Cape Verde in a successful and sustainable manner, which is although is still in the early stages, has an enormous potential for development.

\section{References}

Allen, L. R.; Hafer, H. R., Long, R., \& Perdue, R.R. (1993): "Rural Residents Attitudes toward Recreation and Tourism Development", Journal of Travel Research, 31(4), 27-33.

Allen, L. R.; Long, P. T.; Perdue, R. R., \& Kieselbach, S. (1988): "The Impact of Tourism Development on Residents' Perception of Community Life", Journal of Travel Research, 27(1), 16-21.

Anderek, K.L. et al. (2005): "Residents' perceptions of community tourism impacts", Annals of Tourism Research, 32(4), 1056-1076.

Ap, J. (1992): "Residents' perception on tourism impacts", Annals of Tourism Research, 19 (4), 665-690.

Belisle, F. J., \& Hoy, D.R. (1980): "The Perceived Impact of Tourism by Residents: A Case Study in Santa Marta, Columbia", Annals of Tourism Research, 7, 83-101.

Besculides, A., Lee, M., \& McCormick, P. (2002): "Residents' perceptions of the cultural benefits of tourism", Annals of Tourism Research, 29, 303-319.

Bujosa, A., \& Roselló, J. (2007): "Modelling environmental attitudes toward tourism", Tourism Management, 28 (3), 688-695.

Cannan, P., \& Hennessy, M. (1989): "The growth machine, tourism and the selling of culture", Sociological Perspectives, 32, 227-243.

Carlisle, S., Kunc, M., Jones, E., \& Tiffin, S. (2013): "Supporting innovation for tourism development through multi-stakeholder approches: Experiences from Africa", Tourism Management, 35, 59-69.

Cater, E. A. (1987): "Tourism in the Least Developed Countries", Annals of Tourism Research, 14, $202-226$.

Cohen, E. (1988): "Tourism and aids in Thailand", Annals of Tourism Research, 15, 467-486.

Cook, K. S.; Cheshire, C.; Rice, E. R., \& Nakagawa, S. (2013): Social exchange theory. Handbooks of Sociology and Social Research, Chapter 3, 61-88, Springer Netherlands.

Davis, D.; Allen, J., \& Cosenza, R. M. (1988): "Segmenting local residents by their attitudes, interests, and opinions toward tourism", Journal of Travel Research, 27, 2-8.

Díaz, R., \& Gutiérrez, D. (2010): "La actitud del residente en el destino turístico de Tenerife: evaluación y tendencia", PASOS, Revista de Turismo y Patrimonio Cultural, 8 (4), 431-444.

Diedrich, A., \& García-Buades, E. (2009): "Local perceptions of tourism as indicators of destination decline", Tourism Management, 30, $512-521$.

Esman, M. (1984): "Tourism as ethnic preservation: The Cajuns of Louisiana", Annals of Tourism Research, 11, 451-467.

Gee, C. Y.; Mackens, J.C., \& Choy, D. J. (1989): The Travel Industry. Van Nostrand Reinhold. New York NY.

Gunn, C. A. (1988): Tourism Planning. Taylor \& Francis. New York NY.

Gursoy, D., \& Jurowski, C. (2000): "Resident attitudes in relation to distance from tourist attractions", Travel and Tourism Research Association, http://www.ttra.com

Gursoy, D.; Jurowski C., \& Uysal, M. (2002): "Resident attitudes: A Structural Modeling Approach", Annals of Tourism Research, 29 (1), 
79-105.

Harril, R. (2004): "Residents' attitudes toward tourism development: a literature review with implications for tourism planning", Journal of Planning Literature, 18 (1), 251-266.

Harris, C.; Mclaughlin, W., \& Brown, G. (1998): "Rural communities in the interior Columbia Basin: How resilient are they?", Journal of Forestry, 96, 11-15.

Harrison, D. (1992): Tourism to less developed countries: The social consequences in tourism and less developed countries, Bellhaven. London.

Imran,S.; Khorshed, A., \& Beaumont, N. (2014): "Environmental orientations and environmental behavior: Perceptions of protected area tourism stakeholders", Tourism Management, 40, 290-299.

Jurowski, C.; Uysal, M., \& Williams, R. D. (1997): "A Theoretical Analysis of Host Community Resident Reactions to Tourism", Journal of Travel Research, 36 (2), 3-11.

Jurowsky, C., \& Gursoy, D. (2004): "Distance effects on residents' attitudes toward tourism". Annals of Tourism Research, 31 (2), 296304.

Keogh, B. (1990): "Resident and Recreationists' Perceptions and Attitudes with Respect to Tourism Development", Journal of Applied Recreation Research, 15(2), 71-83.

Ko, D., \& Steward, W. (2002): "A structural equation model of residents' attitudes for tourism development", Tourism Management, 23, 521-530.

Kousis, M. (1989): "Tourism and the family in rural Cretan community", Annals of Tourism Research, 16, 318-332.

Lankford, S. V., \& Howard, D. R. (1994): "Developing a Tourism Attitude Impact Scale", Annals of Tourism Research, 21, 121-139.

Lanquar (1985): Sociologie du tourisme et des vouyages, Presses Universitaires de France. Paris.

Lawton, L., \& Weaver, D.B. (2015): 'Using residents' perceptions research to inform planning and management for sustainable tourism: a study of the Gold Coast Schoolies Week, a contentious tourism event", Journal of Sustainable Tourism, 23 (5), 660-682.

Lindberg, K., \& Johnson, R. (1997): "Modeling residents' attitudes toward tourism", Annals of Tourism Research, 24(2), 402-424.

Liu, J. C., \& Var, T. (1986): "Residents Attitudes toward Tourism Impacts in Hawaii", Annals of Tourism Research, 13, 193-214.

Liu, J. C.; Sheldon, P.J., \& Var, T. (1987): "Residents Perceptions of the Environmental Impacts of Tourism", Annals of Tourism Research, 14, 17-37.

Long, P. T.; Perdue, R. R., \& Allen, L. (1990): "Rural Resident Tourism Perceptions and Attitudes by Community Level of Tourism", Journal of Travel Research, 28(3), 3-9.

Madrigal, R. (1993): "A tale of tourism in two cities", Annals of Tourism Research, 20, 336-353.

Marrero, J. R. (2006): "El discurso de rechazo al turismo en Canarias: una aproximación cualitativa", Pasos. Revista de turismo y patrimonio cultural, 4 (3), 327-341.

Mathieson, A., \& Wall, G. (1982): Tourism: Economic, Physical, and Social Impacts. Longman House. New York.

Mazón, T. et al. (2009): "Tourism dependence and host community perceptions. Notes on the social exchange theory", Encontros Cientificos - Tourism and Management Studies, 5, 25-37.

Mcintosh, R. W., \& Goeldner, C. R. (1990): Tourism Principles, Practices, Philosophies. Wiley. New York.

Monterrubio, J.C. (2008): "Residents' perception of tourism: a critical theoretical and methodological review", Ciencia ergo sum, 15 (1), 35-44.

Murphy, P. E. (1983): "Community Attitudes to Tourism", Tourism Management, 2, 189-195.

Murphy, P. E. (1985): Tourism: A Community Approach. Routledge. New York.

National Cape Verdean Institute of Statistics (2015): Datos estadísticos, Praia, Servicio de Publicaciones.

OMT (1999): Guía para administradores locales: Desarrollo Turístico Sostenible, OMT. Madrid.

Pizam, A. (1978): "Tourism's Impacts: The Social Costs to the Destination Community as Perceived by its Residents". Journal of Travel Research, 16(4), 8-12.

Puczko, L., \& Ratz, T (2000): "Tourist and resident perceptions of the physical impacts of tourism at Lake Balaton, Hungary: Issues for sustainable tourism management", Journal of Sustainable Tourism, 8, 458-478.

Ribeiro, M. A; Do Valle, P. O., \& Silva, J. A. (2013): "Residents' attitudes towards tourism development in Cape Verde islands", Tourism Geographies, 15(4), 654-679.

Ritchie, B.W., \& Inkari, M. (2006): "Host community attitudes toward tourism and cultural tourism development: the case of the Lewes District, Southern England", International Journal of Tourism Research, 8(11), 27-44.

Ritchie, J. R. B. (1988): "Consensus Policy Formulation in Tourism", Tourism Management, 9, 199-216.

Rothman, R. A. (1978): "Residents and Transients: Community Reaction to Seasonal Visitors", Journal of Travel Research, 16(3), 8-13.

Royo, M., \& Ruiz, M. E. (2009): "Actitud del residente hacia el turismo y el visitante: factores determinantes en el turismo y excursionismo rural-cultural", Cuadernos de Turismo, 23, 217-236.

Santana, A. (1997): Antropología y Turismo, ¿Nuevas hordas, viejas culturas? Ed. Ariel, SA. Madrid.

Sethna, R., \& Richmond, B. (1978): "U.S. Virgin islanders' perceptions of tourism", Journal of Travel Research, 17(1), 30-37.

Sharma, B. et al. (2008): "Structural modeling of resident perceptions of tourism and associated development on the Sunshine Coast, Australia", International Journal of Hospitality and Tourism Administration, 9(3), 288-311.

Sharpley, R. (1994): Tourism, tourists and society, ELM. Huntingdon:.

Sheldon, P. J., and Var, T. (1984): "Resident Attitudes to Tourism in North Wales", Tourism Management, 5, 40-47.

Sook, F.; May L.; Songan P., \& Nair V. (2014): "The impact of Local Communities' Involvement and Relationship Quality on Sustainable 
Tourism in Rural", Procedia-Social and Behavioral Sciences, 144, 60-65.

Swain, M. B.et al. (1998): "Annals and tourism evolving: index in 25 years of publication", Annals of Tourism Research, 25 supplements, 991-1014.

Tosum, C. (2002): "Host perceptions of impacts: A comparative tourism study", Annals of Tourism Research, 29, 231-245.

Tyrell, T. J., and Spaulding, I. A. (1984): "A survey of attitudes toward tourism growth in Rhode Island", Hospitality Education and Research Journal, 8(2), 22-33.

Um, S. and Crompton, J.L. (1987): "Measuring Resident's Attachment Levels in a Host Community", Journal of Travel Research, 26(2), 27-29.

Var, T.; Kendall, K. W. and Tarakcoglu, E. (1985): "Residents Attitudes toward Tourists in a Turkish Resort Town", Annals of Tourism Research, 12, 652-658.

Vargas, A. et. al. (2007): Desarrollo del turismo y percepción de la comunidad local: factores determinantes de su actitud hacia un mayor desarrollo turístico. XXI Congreso Anual AEDEM, University Rey Juan Carlos, Madrid, 6,7, y 8 de junio de 2007/Vol.1, pg. 24, coord. by Carmelo Mercado Idoeta. 